\title{
Economics of ecological and biological development of the agro-industrial complex of the Chechen Republic
}

\author{
Kheda Murtazova* \\ Chechen State University named after A.A. Kadyrov, 364024, st. Sheripova, 32, Grozny, Russia
}

\begin{abstract}
The agro-industrial complex of the Chechen Republic is a complex mechanism, the effective functioning of which is possible only if its condition is objectively assessed, its needs and development prospects are determined, the structure of production and management is formed, and a number of other fundamental issues are resolved. Taking measures to strengthen existing forms and business entities is of great importance. This is due to the fact that the overwhelming majority of state farms, KLF and other agricultural producers, due to objective and subjective reasons, have an underdeveloped agricultural culture, poorly provided material and technical base and, as a result, a low level of productivity of agricultural sectors, there is an excessive increase in costs for production and, accordingly, a significant share of agricultural products is unprofitable.
\end{abstract}

\section{Introduction}

One of the main problems of greening the Russian economy is concentrated in the agroindustrial complex (AIC). The low efficiency of the use of natural resources and the high nature intensity of the Russian economy as a whole is largely determined by the current state of the agro-industrial complex (AIC). A feature of modern social development is the awareness of the relationship between economic and environmental development [3].

It is necessary to introduce new technologies in the food industry, including bio- and nanotechnologies, which will significantly expand the production of new generation products with specified quality and environmental characteristics. The priorities in the development of the agro-industrial complex (AIC) are: transition to resource-saving technologies that ensure waste-free production and production with minimal environmental impact; production of organic food; environmental safety of food; carrying out technical reequipment, with the introduction of modern achievements of scientific and technological progress to reduce energy consumption, reduce harmful emissions into the environment and increase the profitability and competitiveness of products, increase profits [2].

The agro-industrial complex unites all sectors of the economy involved in the production of agricultural products, their processing and delivery to the consumer. The importance of the agro-industrial complex lies in providing the country with food and some

\footnotetext{
*Corresponding author: fu.ggni@mail.ru
} 
other consumer goods. The most common agribusiness model typically includes three main areas. The first area includes industries that produce means of production for agriculture and industries that process agricultural raw materials: tractor and agricultural engineering, production of equipment for animal husbandry, food and light industries, production of mineral fertilizers, feed and microbiological industries, and agricultural construction. The second area is agriculture itself (agriculture and animal husbandry). The third area is the system of industries for industrial processing and marketing of agricultural raw materials and food: food, light industry, procurement system, transportation, storage and sale of agricultural products. The location of the first and third links of the agro-industrial complex is largely determined by the territorial organization of agricultural production. Processing, warehousing and storage of agricultural products is largely consumer-oriented. Territorial concentration in suburban areas and highly urbanized areas of production of potatoes, vegetables and other crop products is also due to the revitalization of households and farmers.

\section{Methods}

The modern world sets new tasks for agricultural producers. Population and income growth, coupled with dietary diversification, is changing food consumption patterns and exacerbating the aggregate pressure on natural resources - soil, water, energy and biodiversity. Over the past half century, food production has slightly outpaced the rate of population growth: the annual increase in the productivity of agrocenoses over the past three decades has averaged 2.2\%. According to experts, by 2030 it will slow down and will be about $1.5 \%$.

In this regard, the need to develop agriculture as a tool for the sustainability of ecosystems and improve the quality of life of the population should be obtained by increasing the return from 1 hectare of cultivated land, which is also a way to preserve diversity. This is quite difficult to achieve, since, on the one hand, according to the findings of the International Research Institute for Food Policy Development, 70\% of the world's average arable land is degraded due to erosion processes, soil depletion, and salinization. Moreover, $30-40 \%$ of these areas are classified as highly degraded. Modern agriculture has become more knowledge-based and today responds to economic, social and environmental challenges with effective, holistic and integrated solutions. Of particular importance is the development of innovative approaches to optimizing land use, including methods of soil conservation farming systems that reduce water outflow, prevent soil erosion, reduce fuel consumption of machines and mechanisms, and contribute to the deposition of carbon dioxide in soils, water bodies and forests [4].

A systematic approach to the management of agricultural production is needed in order to reduce the uncertainty in decision-making, which is achieved by improving the understanding of spatio-temporal variability and improving its management system. Most of the tasks of this system are associated with the optimization of the use of nutrients, the use of pesticides, water and energy intensity of production. These include:

1.Economic challenge:

-determination of effective forms of organization of production;

-permanent accounting of the availability, movement and expenditure of resources;

- cost management;

- the introduction of progressive incentives to save resources, pricing and implementation policies.

2.Environmental challenge: 
-optimization of the relationship of agro-industrial production with the environment based on the restoration of soil fertility, energy resources, water balance and balance of mineral resources.

Agriculture has made significant progress, however, in order to meet the requirements of the time, it is necessary to increase its profitability, and a high-quality environment is a determining factor in strategic development. Lack of economic interest does not allow domestic agricultural producers to fully apply environmental and resource-saving technologies and carry out a set of works to increase soil fertility and improve the technical condition of lands. All-round resource conservation, protection and reproduction of natural resources must be ensured by an effective regulatory mechanism. In this regard, the substantiation of various types of resource-saving production methods and the development of an optimal development strategy, taking into account the rational use of natural resources on the basis of a comprehensive ecological and economic analysis and mathematical modeling, are of great importance [5].

\section{Results}

Among the most effective market economic instruments of environmental regulation aimed at compliance with environmental standards, one can name: payments or taxes for the right to use natural resources; compensation payments for the disposal of natural resources from their intended use or the deterioration of their quality caused by production activities; payments or taxes for emissions of pollutants into the environment; additional tax on profits of enterprises producing environmentally harmful products or using environmentally hazardous technologies [4].

To assess the safety of food products produced by enterprises of the agro-industrial complex (AIC), it is necessary to develop environmental monitoring. A variant of one of them can be the system of chemical and hygienic monitoring developed at the Department of Inorganic and Analytical Chemistry of MGUPP to ensure the determination of the concentration level of trace elements in food, the index of their contamination and their compliance with sanitary and hygienic standards. In this environmental monitoring, a complex of developed new sensitive and reproducible combined analytical methods is used, which allows a differentiated analysis of trace elements with a sensitivity of $0.001-0.005 \mu \mathrm{g}$ $/ \mathrm{ml}$, and the identification of chemically active forms of trace elements that determine the true criteria of their toxicity based on combined schemes for the isolation of trace elements.

Financing environmental activities and environmental auditing are two interrelated socially significant economic methods in the field of solving sectoral environmental problems. The agro-industrial complex (AIC) in a market economy, where the only scarce resource is money, the decisive factor in the effectiveness of environmental measures is the sustainability of their financial support. Bank loans are one of the sources of financing for environmental programs (activities) of enterprises of the agro-industrial complex (AIC). This financial and credit mechanism is also an important lever of environmental and economic incentives, including concessional lending for environmental activities [6].

The policy of preferential environmental lending implies the provision of preferential loans for environmental purposes from the budget, as well as the attraction of bank loans. However, the use of concessional loans in this area does not find appropriate support from the state. The possibility of using loans from domestic banks to finance environmental activities is limited due to the excessively high interest rate on loans.

The advantages of bank lending in comparison with the budget is the observance of the principles of payment and repayment of the funds provided, which should stimulate the only targeted use of loans and the minimum time frame for environmental measures. At the 
same time, the state can provide the creditor bank with a tax incentive (reduction of the tax rate on income), thereby encouraging banks to lend environmentally. The state can also provide the bank with a subsidy to compensate for the loan at a reduced interest rate. This gives a guarantee of repayment and repayment of the loan. If an enterprise has its own environmental fund (which is currently problematic for enterprises of the agro-industrial complex (AIC), but becomes necessary), it can guarantee the repayment of the loan by this fund. Perhaps the solution to the problem of repayment of bank funds will require the creation of mortgage banks.

In a market economy, when carrying out risky operations, such as preferential environmental lending, long-term investments, it is necessary to apply the generally accepted international practice of the relevant environmental procedures, in particular, environmental audit (eco-audit). Currently, many commercial banks to reduce the risk of financing use environmental audits in order to obtain reliable environmental information on property, current operations, emergency management system, environmental program of the funded enterprise.

\section{Discussion}

An analysis of the activities of agricultural enterprises in the Chechen Republic over the past 5 years shows that the reasons for their low efficiency, first of all, lie in the fact that the priority directions for the development of the agricultural sector and the processing industry have not been determined. In particular, there is no clear policy for meeting state needs for food, state purchases of agricultural products are fully or partially frozen, due to the destroyed economy of industries processing agricultural products [1-2].

As a result, the products grown by agricultural producers do not have stable sales markets, as a rule, lacking production capacities for processing and storage leads to the loss of grown agricultural products The introduction of a state order system for agricultural products, through the restoration of enterprises processing agricultural products, at this stage would serve as a solution problems of commodity producers of all organizational and legal forms, in the conditions of the Chechen Republic.

The effectiveness of state support for agriculture in developed countries is ensured by the use of the following mechanisms: proven by many years of practice of using instruments of regulatory state support for agricultural production, aimed at stabilizing incomes, certified by the relevant legislative acts; division of all state resource support into parts: mandatory and additional, and the level of additional support is determined by new priorities of state policy in agriculture; the presence of a stable system of standards in the instruments of state support, which provides the necessary level of interest of rural producers in the development of agricultural production due to its predictability. [eight]

World experience shows the need to use forms and methods of state resource support integrated with market mechanisms. These include: depreciation policy, the use of leasing mechanisms in combination with preferential ones. lending, jointly with commercial risk insurance structures, exclusion of protectionism in obtaining compensation and subsidies in relation to. A significant impetus to the development of the branches of the agro-industrial complex of the republic can be given by federal and republican authorities, providing subsidies and loans depending on the volume of products and quality, on the funds spent, as well as implementing a competent investment policy. In the period of economic recovery, a set of measures is necessary to optimize resource support for the agro-industrial complex of the Chechen Republic at the federal and regional levels, improve the financial and credit tax policy, and distribute the functions of regulating the leasing process at the federal regional levels. It is necessary to introduce a state system for monitoring the economic processes of 
agricultural production, that is, the creation of continuous monitoring of economic parameters, which makes it possible to assess the main reproductive proportions of agriculture, the profitability of production, the level and dynamics of crop rotations, soil fertility, etc. alternative market financing mechanisms to be sought in investing in rehabilitated and newly created high-performance enterprises, whose investors would be individuals and organizations. The relevance of streamlining land relations and the centralization of the function of regulating them is due to the fact that more than $18 \%$ of the arable land in the republic was arbitrarily seized by citizens; a significant part of the land in recent years has not been cultivated and has fallen into disrepair (including more than 50\% of the land transferred to the management of peasant farms, cooperatives); the facts of the rejection of land by the decision of local self-government bodies without appropriate legal registration have become widespread [9].

In order to restore the rule of law in matters of land use and determine the boundaries of land use, it is proposed: to cancel all illegally adopted decisions on the transfer of land, eliminate squatters and complete the development of the land cadastre of the republic in the process of its implementation, it is necessary to involve commodity producers of all organizational and legal forms. Next, there should come a stage associated with the creation of multi-structure and the introduction of new highly efficient forms of management in the agricultural sector of the economy. To this end, it is necessary to reorganize and liquidate unpromising state farms and other unprofitable enterprises, to create on their basis various small-scale forms of management, focused mainly on private capital investments. Along with this, options are also provided for the restoration of food and processing industry enterprises that do not require significant capital investments. Gradual commissioning of workshops and sections of large enterprises, provided that the recovery cycle does not exceed one year of enlargement of farms and the creation on their basis of joint-stock companies and enterprises of other organizational and legal forms. The priorities for the development of agricultural and processing industries are determined based on the needs of their own environmentally friendly food products for the population of the republic, in this regard, it is necessary to establish integration ties with the subjects of the region on mutually beneficial cooperation in such areas as the food industry, vegetable growing, horticulture, seed growing, processing grapes, wild berries, fruits and medicinal herbs, joint participation in investment projects [10].

\section{Conclusion}

The agro-industrial complex is one of the most important sectors of the republic's economy and is of strategic importance for the republic. Considering that more than $60 \%$ of the population lives in rural areas and it is in the countryside that the main contingent of the unemployed. The republic's agriculture specialized in the cultivation of cereals, legumes, industrial and oil crops, vegetables. Horticulture, viticulture, as well as livestock and poultry farming were developed. The priorities for the development of the agro-industrial complex include animal husbandry, plant growing, horticulture and viticulture, storage and processing of agricultural products, as well as restoration and development of the water management complex and land reclamation for agricultural purposes. This will increase the volume of agricultural production for the population and provide raw materials for the food and processing industry of the republic. The yield of grain crops shows that the republic is quite capable of providing itself with its own bread, and this is important in modern conditions. The production of industrial crops, vegetables, fruits, livestock products and their processing are being restored. Attracting investments in the agro-industrial complex of the republic will significantly increase the area under agricultural crops, there will be an 
opportunity to launch and reach the full production capacity of enterprises processing agricultural products, as a result of which tens of thousands of people will be provided with jobs [10].

\section{References}

1. I.A. Bayrakov, R.A. Gakaev, Geoecological foundations of the use of natural resources and environmental protection in the Chechen Republic, 58 (2018)

2. A.A. Bokarev, Green Investments in Russia: Search for Priority Areas (2017)

3. T.V. Zakharova, «Green» economy as a new course of development: global and regional aspects (2018)

4. Federal national project «Ecology» (2018)

5. S. G. Tyaglov, Modern aspects of the development of the «green economy» in the Russian Federation, 104 (2017)

6. M.V. Onishchenko, The role of the state in the development of the «Green Economy», $560(2020)$

7. O.D. Ermolenko, Problems and prospects for the development of viticulture on the basis of state support, 362 (2020)

8. V.I.Kiryushin, Ecological foundations of agriculture, 267 (2000)

9. H. Buller, G.A.Wilson G.A., Agri-environmental policy in the European Union: Ashgate. Aldershot, 291 (2020)

10. L. Lohr, T. Park, L. Higley,Farmer risk assessment for voluntary insecticide reduction (2019) 